NEW DEMONS 



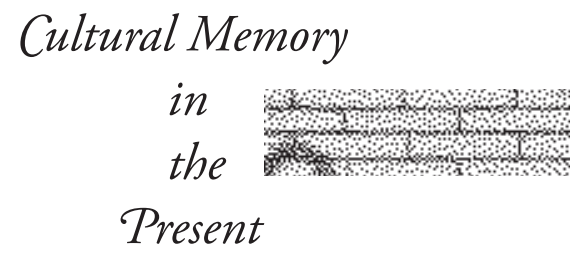

Hent de Vries, Editor 



\section{NEW DEMONS}

Rethinking Power and Evil Today

Simona Forti

Translated by Zakiya Hanafi

STANFORD UNIVERSITY PRESS

STANFORD, CALIFORNIA 
Stanford University Press

Stanford, California

English translation (C20I5 by the Board of Trustees of the Leland Stanford Junior University. All rights reserved.

First published as I nuovi demoni in March 2012 by Giangiacomo Feltrinelli

Editore, Milan, Italy. Copyright (C) Giangiacomo Feltrinelli Editore, 2012.

The translation of this work has been funded by SEPS

Segretariato Europeo per le Pubblicazioni Scientifiche

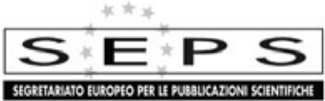

Via Val d'Aposa 7 - 40I23 Bologna - Italy

seps@seps.it - www.seps.it

No part of this book may be reproduced or transmitted in any form or by any means, electronic or mechanical, including photocopying and recording, or in any information storage or retrieval system without the prior written permission of Stanford University Press.

Printed in the United States of America on acid-free, archival-quality paper

Library of Congress Cataloging-in-Publication Data

Forti, Simona, author.

[Nuovi demoni. English]

New demons : rethinking power and evil today / Simona Forti ; translated by Zakiya Hanafi.

pages $\mathrm{cm}--($ Cultural memory in the present)

"First published as I nuovi demoni in March 2012 by Giangiacomo Feltrinelli Editore, Milan, Italy."

Includes bibliographical references and index. ISBN 978-0-8047-8624-9 (cloth : alk. paper)-ISBN 978-0-8047-9295-o (pbk. : alk. paper)

I. Good and evil. 2. Power (Philosophy) 3. Ethics, Modern--I9th century.

4. Ethics, Modern--2oth century. 5. Political science--Philosophy. I. Title.

II. Series: Cultural memory in the present.

BJI404.F67I3 2014

I70--dc23

2014025922

ISBN 978-0-8047-9298-I (electronic)

Typeset by Bruce Lundquist in II/13.5 Adobe Garamond 
In memory of Linda.

To the unpredictable with Marco and Pietro. 

Everything that isn't autobiographical is plagiarism.

PEDRO ALMODÓVAR 
